The famous Neanderthal remains were found in 1857 , and are usually regarded as the first discovered remains of that remarkable race of early Europeans now known by the name of Neanderthal man (Homo primigenius, Schwalbe). It will be thus seen that the Gibraltar cranium was the first discovered trace of Neanderthal man, having been found nine years before the type-specimen.

The second letter is from Dr. Hugh Falconer to Mr. George Busk. The date of the letter was certainly 1864; Dr. Falconer and Mr. Busk were then preparing a report on a large collection of fossil remains from caves at Gibraltar for the British Association meeting at Bath in that year. In this collection was the famous cranium. The collection was made and sent home by Captain Brome, who was in charge of the garrison prison. Unfortunately, his scientific enthusiasm led to his dismissal from his post and from the Services; he had employed prisoners to help him in the scientific investigations which led to the discovery of the remarkable cave fauna of Gibraltar. Mr. Busk took a leading part in obtaining from fellow men of science financial sympathy on behalf of Captain Brome.

$$
21 \text { Park Crescent, }
$$

August 27 (1864).

" My Dear Busk,

"A hint or two about the names which. I have been rubbing up for the Priscan Pithecoid skull, Homo var. calpicus, from Calpe, the ancient name for the Rock of Gibraltar. What say you?

"For the characters of the face: as all the pros, orthos, katas, \&c., are already engaged in conjunction with gnathos, we must look elsewhere. В $\lambda \epsilon \mu \mu \alpha-a s p e c t u s$, vultus for a foundation sound well and appropriate-e.g. $B \lambda \epsilon \mu \epsilon a \iota \nu \hat{\omega}$ "truculus oculis circumspicio." I am sure Pithecoid must have looked terribly truculent.

"Now for the combination. Pro-blemmatous at a pinch might do, but I doubt the soundness of the combination, and I think a better might be agrioblemmatous, from aypıs, wild or savage, and Btєuua. By this happy combination you will unite the truculence of the eye and the savagery of the face. Agrioblemmatous is really not a bad idea-it points distinctly to a peculiar savage feature-

"Walk up! ladies and gentlemen. Walk up! and see Professor Busk's Grand, Priscan, Pithecoid, Mesocephalous (!), Prognathous, Agrioblemmatous, Platycnemic, wild Homo calpicus of Gibraltar; Sounds well, anyhow.

"But mesocephalous is French-like-radically wrong. The temporal is a mesocephalous bone of the head; but the skull itself cannot be mesocephalous, or a mid-headed portion of itself. Diacephalous is better than Broca's term.

$$
\text { "Yours ever, }
$$

$$
\text { "H. Falconer." }
$$

The letter shows that the veteran Scot, the pioneer of the Siwalik fauna, had a sense of humour, a facility in coining names, and a very clear conception that Homo calpicus was a very distinct variety of mankind. The cranium was duly exhibited at the meeting of the British Association at Bath in 1869 , but there is no record in the report of what Mr. Busk said about the skull (except as to where it was found and that it resembled the Neanderthal specimen) nor of Dr. Falconer's taxonomic suggestions.

A. KEITH.

Royal College of Surgeons, Lincoln's Inn Fields, W.C.

\section{A New Mineral?}

What may prove to be a new mineral has been obtained from the Du Toits Pan Mine at Kimberley. The material is in two forms: irregular pieces up to half a pound in weight, and small round pellets, which, collected together in a heap, would be mistaken for mixed shot. Some specimens are dull like lead on the outside, while others have a resemblance to polished nickel. The prevailing inside texture is spongy-looking. Under the microscope some of the surfaces are seen to be pitted with holes where the spongy texture reaches the surface. On the other hand, some of the larger pieces have wrinkled surfaces, not pitted; others have bright surfaces intersected with tiny cracks. Many of the specimens are covered with a blackish NO. 2 I 84 , VOL. 87$]$ coating of about the thickness of paint. This is probably graphite; it scrapes off easily enough.

The specific gravity is on the whole something higher than 6.7 , but by exactly how much higher it is difficult to say, on account of the porosity of the material. The hardness ranges high, varying from about 6 on a fractured face and on the duller outside surfaces to upwards of 9 on some of the bright surfaces. It is attracted by the magnet to a moderate extent-some pieces very feebly. It is very brittle, and on fracture gives off a strong smell of carbide.

Mr. W. Versfeld, Government analyst, Cape Town, makes out the following analysis:-

$$
\begin{aligned}
& \begin{array}{lllllll}
\text { Iron } & \ldots & \ldots & \ldots & \ldots & \ldots & \begin{array}{c}
\text { Per cent. } \\
7 \mathrm{I} \cdot 39
\end{array}
\end{array}
\end{aligned}
$$

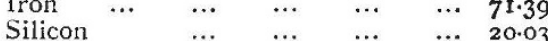

$$
\begin{aligned}
& \begin{array}{lllllr}
\text { Carbon } & \ldots & \ldots & \ldots & \ldots & 8.4 \mathrm{I}
\end{array} \\
& 99.83
\end{aligned}
$$

This composition corresponds approximately with the symbol $\mathrm{Fe}_{13} \mathrm{Si}_{7} \mathrm{C}_{*}$. It appears that in chemical properties this mineral is one of the most refractory of substances. The mineral acids, aqua regia, fused potassium bisulphate, have only a slight action upon it. Roasting at a very high temperature causes no change except a slight tarnishing. Fusion with sodic peroxide, however, causes a ready oxidation. Prof. Schwarz, to whom the material was submitted, has taken a great interest in the find, and calls it, therefore, very aptly, a ferriferous carborundum.

Unfortunately, none of the material has yet been found in situ (nor is it very likely to be, seeing that the supply has now nearly ceased); all of it, so far, has been picked out at Pulsator by the manager, $\mathrm{Mr}$. J. Stewart, in separating the blue-ground for diamonds. Schwarz points out quite truly that in the absence of a specimen in the blue-ground matrix the history of the material is incomplete. Nevertheless, it seemed advisable to put the facts, so far as they are known, on record.

With regard to the origin of the material, Prof. Schwarz writes as follows :- "Dr. P. A. Wagner states in his paper on 'Kimberlite Occurrences in the Pretoria District" (Trans. Geol. Survey of S. Africa, vol. xiv., p. 62, I91I), that on melting up blue-ground in a crucible, metallic globules of iron were obtained usually enclosed in the olivines crystallised from the fused mass. Mr. Thornton Murray examined the largest of these globules and found it to consist of a perlitic grey cast-iron enclosing flakes of graphite; it weighed one gram, but the average globules were smaller. The new mineral from Du Toits Pan Mine is probably of the same nature produced naturally; some local source of heat, frictional or chemical, due to combustion of gas or otherwise, may have raised a portion of the blue-ground to fusion point, and thus produced the globules and masses by reduction of. the ilmenite or even the silicates of iron. The refractory nature of the material renders it possible that it formed as an original constituent of the blue-ground, but the subsequent hydration of the olivine rock to the serpentine breccia would probably have acted more upon the substance than is apparent in the actual specimens. Re-fusion of the hydrated rock seems therefore a more probable explanation."

Kimberley, August I4.

\section{A Miniature Rainbow.}

Jusr about three o'clock this afternoon (I had a few minutes previously asked the time at the village post office) I witnessed a remarkable and very beautiful phenomenon. Coming through a woodland walk, I was caught by a heavy downpour of rain. As it was passing away, the sun shone down from a suddenly clear sky over the tops of the trees behind and to the right. Instantly against a screen of dark alder foliage on the left in front, and distant not more than three yards from where I stood, a perfect miniature rainbow was formed, its highest part being just about level with my eves. It appeared broader than an ordinary rainbow, and much the greater portion was of one deep violet colour, the remaining colours forming merely a narrow border above. Very vivid at first, it quickly faded away, as the shower came to an end. Kilderry, Iondonderry, August 28 . W. F. HART. 